\title{
Technology, Trade, and Wage Inequality in Mexico before and after NAFTA ${ }^{1}$
}

\author{
Gerardo Esquivel \\ El Colegio de México \\ and \\ José Antonio Rodríguez-López \\ University of California, Berkeley
}

This version: July, 2003

\begin{abstract}
Over the past few years, there has been a substantial increase in wage inequality between skilled and unskilled workers in Mexico. This increment in the wage gap coincided with both a period of rapid technological change and the process of trade liberalization in Mexico that began in the mid-eighties. Using a methodology suggested by Leamer (1998), we separate out the effects of technological progress and trade on the real wage evolution of skilled and unskilled workers in Mexico's manufacturing industry for the periods 19881994 and 1994-2000. We find that, as implied by the Stolper-Samuelson theorem, trade liberalization would have led to a reduction in the wage gap in Mexico in the first period. This effect, however, was offset by the large negative impact of technological progress on the real wage of unskilled workers. On the other hand, during the period 1994-2000 the effect of trade liberalization on the wage gap was nil, thus suggesting that the slight increase in wage inequality that occurred in this period was also driven by technological progress.
\end{abstract}

JEL classification: F16, J31

Keywords: Wage inequality, trade liberalization, Stolper-Samuelson, NAFTA.

\footnotetext{
${ }^{1}$ A preliminary version of this paper was presented at the Inter-American Seminar on Economics (IASE) organized by the National Bureau of Economic Research and the Instituto Tecnológico de Monterrey, Campus Monterrey in Mexico, November 15-16, 2002. We thank the excellent research assistance of Alejandra Huerta, Natalia Maldonado and Raúl Mata at different stages of the research. We also thank the very useful comments of Juan Rafael Vargas, Sebastian Edwards, one anonymous referee and participants at the IASE. Financial support from Conacyt (grant G32774D) and from Fondo Ricardo J. Zevada is gratefully acknowledged.
} 


\section{Introduction}

Over the past two decades, there has been a continuous increase in the wage gap between skilled and unskilled workers in several developed and developing countries (OECD, 1997; Gottschalk and Smeeding, 1997; and Wood, 1997). In many developed countries, but particularly in the case of the United States, there has been a heated debate about the underlying causes of such a trend. There have been two main lines of argumentation: First, higher volumes of trade with emerging or low-income countries may have led, through the mechanisms described by the Hecksher-Ohlin model and the Stolper-Samuelson theorem, to a reduction in the relative price of the less-abundant factor in rich countries (namely, unskilled labor). ${ }^{2}$ The intuition is that by increasing trade with unskilled labor-abundant countries, the domestic relative price of products intensive on the developed countries' abundant factor (skilled labor) will rise, and this in turn will be associated to an increase in the relative wages of the abundant factor.

The second line of argumentation suggests that there has been a worldwide skillbiased technological change that has increased the demand for skilled workers relative to that of unskilled workers (Bagwhati, 1995, Krugman and Lawrence, 1993). Some of the authors that favor this explanation for the U.S. case, rule out the possibility that trade could have been the main explanatory factor of the increase in U.S. wage inequality on the basis that U.S. trade with developing countries is relatively small.

Since both arguments are theoretically compelling, a definitive answer about the sources of wage inequality in developed countries was expected to come from empirical studies. However, empirical works based on the U.S. experience provided mixed or weak evidence and therefore did not contribute to resolve the debate. ${ }^{3}$ In light of these results, some authors suggested to bok at the experience of developing countries (i.e. Hanson and Harrison, 1999). They reasoned that, if trade was behind the relative wage movements in developed countries, we should observe a movement in the opposite direction in the relative

\footnotetext{
${ }^{2}$ Wood (1995) and Leamer (1998), among others, have proposed this interpretation.

${ }^{3}$ See, for example, Lawrence and Slaughter (1993) and Sachs and Shatz (1994). According to Leamer (1996), the empirical evidence of these and other similar papers "seems weak or nonexistent" (p. 311).
} 
wages of developing countries. That is, if trade with developing countries was increasing the wage gap between skilled and unskilled workers in developed countries, we should observe a corresponding reduction in the wage gap in the former countries. However, if skill-biased technological change was the main force behind the relative wage movements in developed countries, a similar pattern should be present in developing countries too.

Based on this premise, a number of authors have since then analyzed the relationship between wage inequality and trade in developing countries. ${ }^{4}$ The initial empirical evidence was apparently unequivocal: most developing countries that had gone through episodes of trade liberalization had also experienced a substantial increase in wage inequality (Robbins, 1996a, 1996b). This result led some authors to conclude that skillbiased technological change was pervasive around the world and that it was the main source of wage inequality in both developed and developing countries (i.e. Berman, Bound and Machin, 1998). ${ }^{5}$ However, proponents of the trade hypothesis quickly noted that the fact that middle-income countries were experiencing an increase in wage inequality was not necessarily incompatible with their arguments. These authors emphasized that a country could be at the same time abundant in unskilled labor at a local level, but abundant in skilled labor at a global level (Leamer, 1996). ${ }^{6}$ Therefore, when poor and highly populated countries such as India and China opened their economies to the rest of the world, as they did it in the 1980s, the supply of unskilled labor increased at a worldwide level, and this could explain the pattern of wage inequality observed in middle-income countries (Wood, 1997).

\footnotetext{
${ }^{4}$ See, for example, Hanson and Harrison (1999), Cragg and Epelbaum (1996), Epelbaum and Cragg (1997), Revenga (1997), Feliciano (2001), Meza (1999), Robertson (2001), and Cañonero and Werner (2002) for the case of Mexico; Beyer, et al. (1999) for Chile; Galiani and Sanguinetti (2003) for Argentina; Gonzaga et al. (2002) for Brazil; and Robbins (1996a, 1996b), Wood (1997) for several developing countries. See also IADB (2002) for a recent survey.

${ }^{5}$ Other authors used these findings to suggest an alternative hypothesis for the link between trade policy and wages in developing countries based on political economy arguments. Based on the Mexican case, Hanson and Harrison (1999) suggested that some developing countries may have protected more those industries that used unskilled labor more intensively. Robertson (2001) pursued further this hypothesis and found some favorable empirical evidence. Gonzaga et al. (2002) show that Brazil did not seem to follow this type of policy.

${ }^{6}$ A formal model of this argument is presented in Davis (1996).
} 
This new interpretation complicated again the identification of the role that trade and technology were playing in explaining the increase in wage inequality, since both aspects would be acting in the same direction in both developed and developing countries. In that sense, the resolution to this debate critically depends now on the identification of the contribution of both aspects to the observed pattern of wage inequality.

This paper analyzes the role of technological change and trade liberalization in Mexico's wage inequality between 1988 and 2000. For several reasons, the Mexican case seems appropriate to shed light on the debate of trade versus technology as possible sources of wage inequality. First, Mexico unilaterally reduced its tariff and non-tariff barriers during the mid-eighties and has signed several free trade agreements since the beginning of the nineties. This means that the Mexican economy is one that has recently gone through a period of substantial trade liberalization and we expect that the wage effects of this policy change should show up in the data. Second, most Mexican trade is with countries that are definitely more abundant on skilled labor. Throughout the 1988-2000 period, more than 93\% of total Mexican external trade was with the U.S., Canada, Europe and Japan. This means that if the implications of the Stolper-Samuelson theorem are correct, therefore Mexico is a good candidate for a country where we should expect to observe a reduction in wage inequality as a result of having higher volumes of international trade. Also, if skillbiased technological change is important, therefore we should expect that these two aspects, trade and technology, should be operating in different directions and that the observed wage movements should be a reflection of the relative importance of both aspects. Third, the fact that Mexico signed in 1992 the North American Free Trade Agreement (NAFTA) with much more developed countries such as Canada and the U.S., suggests that we should expect a deepening of the effects of trade on wage inequality in the post-NAFTA period. ${ }^{7}$ It is important to stress that we should not expect a change in the role of trade liberalization on wage inequality as a result of NAFTA, since it did not mean a qualitative change in trade policy. ${ }^{8}$

\footnotetext{
${ }^{7}$ NAFTA was signed in 1992, but it came into effect on January $1^{\text {st }}, 1994$.

${ }^{8}$ This interpretation stands in sharp contrast with that of Robertson (2001). According to him, the preNAFTA period represented an opening of Mexico to the rest of the world, whereas NAFTA represented the opening of Mexico to more developed countries. Therefore, he argues, it is reasonable to expect a change in
} 
In order to identify the contribution of technology and trade to the observed pattern of wage inequality in Mexico, we estimated "mandated-wage" equations as suggested by Leamer (1998). ${ }^{9}$ This methodology, as such, has not been previously applied for developing countries. $^{10}$ Based on the observed pattern of wage inequality in Mexico, we estimate product-price regressions for the sub-periods 1988-1994 and 1994-2000. The motivation for this division is to analyze separately the pre-NAFTA and the post-NAFTA periods. As mentioned before, there are enough reasons to believe that the effect of trade on wage inequality in Mexico must be qualitatively similar before and after NAFTA, but the magnitude of such effect may have increased as a result of the greater economic integration between Mexico and more developed countries such as the United States and Canada.

Besides this introduction, section II provides the stylized facts on trade liberalization and wage inequality in Mexico. Section III presents a brief survey of the literature on the sources and determinants of wage inequality in Mexico. Section IV describes the methodology and data that we use in our empirical exercise. Section V presents the empirical results. Finally, Section VI concludes.

\footnotetext{
the role of trade on wage inequality as a result of NAFTA. This interpretation would be correct if the reduction of Mexico's trade barriers of the mid-eighties had been circumscribed to less-developed countries, or if there had been a notorious change in the pattern of Mexico's external trade as a result of NAFTA. None of these is true.

9 Baldwin and Cain (2000), Krueger (1997), and Haskel and Slaughter (2000) have used a methodology closely related to that of Leamer's. See Slaughter (2000) for a survey of nine studies using related methodologies.

${ }^{10}$ Robertson (2001), for the case of Mexico, and Gonzaga et al. (2002) for the case of Chile, reported similar, although not identical exercises. Instead of following Leamer (1998), they followed a variation suggested by Feenstra and Hanson (1995).
} 


\section{Trade Liberalization and Wage Inequality in Mexico}

\section{Trade Liberalization in Mexico}

Sometime around 1940, Mexico adopted an import substitution industrialization strategy. This strategy consisted in protecting its industrial sector through a set of tariff and nontariff barriers in order to promote the creation of new industries and to permit the development of those already existing. As a result, between 1940 and 1985, Mexico operated basically as a closed economy. ${ }^{11}$ In 1985, in the midst of the debt crisis and as a result of the collapse of the oil price, Mexico initiated an important process of trade liberalization. $^{12}$ In that year, Mexico implemented a considerable unilateral reduction in trade barriers and announced its intention to participate in the General Agreement on Tariffs and Trade (GATT).

Table 1 shows some indicators of protection in Mexico for 1985, 1988 and 1993. It illustrates the dramatic change in protection levels that occurred between 1985 and 1993. In these years, the domestic product covered by import permits went from $92 \%$ in 1985 to only $16.5 \%$ in 1993 , whereas the percentage of fractions subject to permits diminish from $10 \%$ in 1985 to less than $2 \%$ in 1993 . The table also shows that by 1988 , our initial year of analysis, most of the changes in the structure of production had already taken place.

Table 1. Mexico: Indicators of Protection

\begin{tabular}{|cccccc|}
\hline & $\begin{array}{c}\text { Domestic Product } \\
\text { Covered by } \\
\text { Import Permits } \\
\text { Year }\end{array}$ & $\begin{array}{c}\text { Production-Weighted } \\
\text { Average tariff } \\
(\%)\end{array}$ & $\begin{array}{c}\text { Maximum Tariff } \\
(\%)\end{array}$ & $\begin{array}{c}\text { Imports } \\
\text { Subject } \\
\text { to Permits } \\
(\%)\end{array}$ & $\begin{array}{c}\text { Fraction Subject } \\
\text { to Permits }\end{array}$ \\
\hline 1985 & 92.2 & 23.5 & 100.0 & 35.1 & 10.4 \\
1988 & 23.2 & 11.0 & 20.0 & 21.2 & 3.4 \\
1993 & 16.5 & 12.5 & 25.0 & 21.5 & 1.6 \\
\hline
\end{tabular}

Source: Tornell and Esquivel (1997).

\footnotetext{
${ }^{11}$ There was an incipient process of liberalization in the late 1970s, but it was quickly reverted as a result of the Mexican debt crisis of 1982.

${ }^{12}$ For more details on the trade liberalization process in Mexico see Tornell and Esquivel (1997).
} 
In order to complete the structural change in its trade policy initiated in the mideighties, in 1990 Mexico announced its intentions to begin formal talks with the U.S. and Canada to sign up a North American free trade agreement (NAFTA). In December of 1992 the three countries signed NAFTA, which was then scheduled to come into effect on January 1, 1994. It is important to stress that NAFTA was the first asymmetric free trade agreement in terms of the income levels of the participating countries.

The immediate effects of the radical change in Mexican trade policy can be easily perceived in figures 1 and 2. The first figure shows Mexican imports and exports between 1975 and 2000. The figure shows the explosive growth in Mexico's external trade that began around 1985 and that has continued ever since. In terms of percentage of GDP, Mexico's total foreign trade grew from $26 \%$ in 1985 to $38 \%$ in 1994 and then to $65 \%$ in 2000. Figure 2, on the other hand, shows the import penetration ratios in the manufacturing industry for the years 1988, 1994, and 2000. This figure shows that the import penetration rate in the manufacturing industry as a whole has grown from 45\% in 1988 to more than $150 \%$ in 2000. Moreover, this increase has occurred at the industry-wide level, and it has been particularly important in the textile and basic metals industries.

Figure 1. Mexico: Exports and Imports, 1975-2001

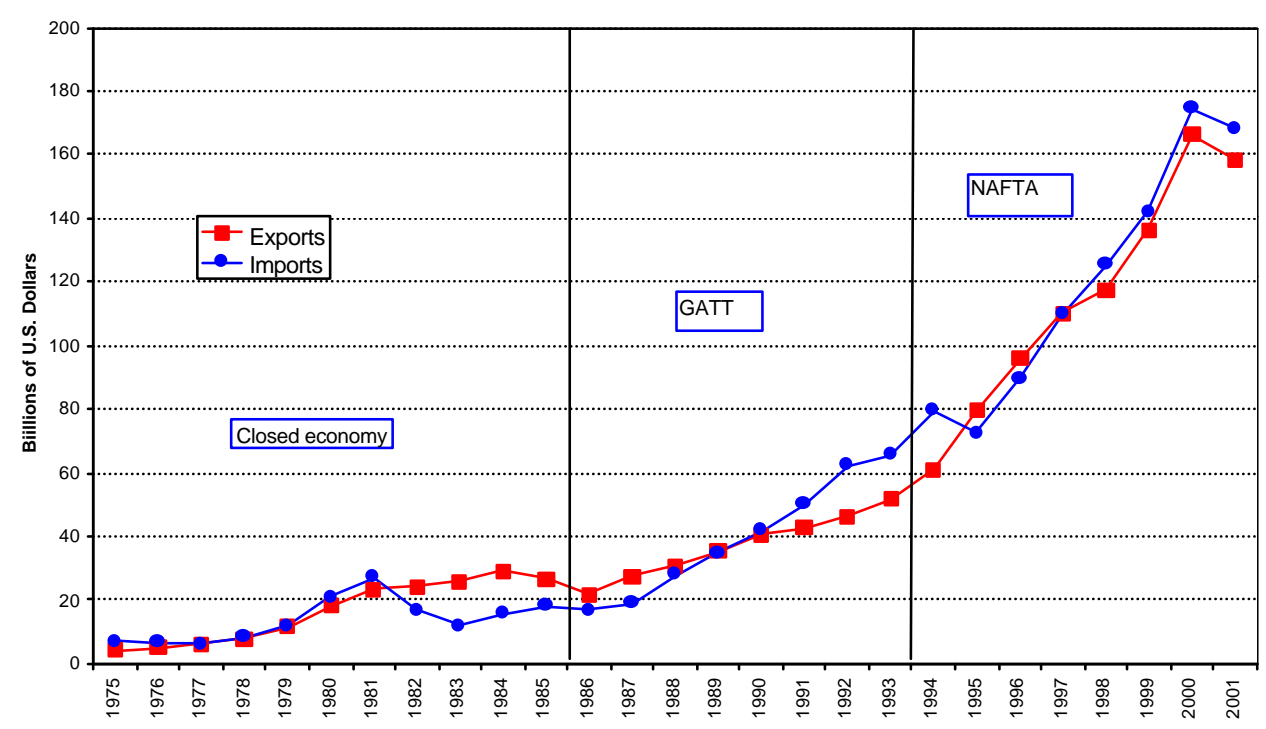


Figure 2. Import Penetration Rates in Mexico's Manufacturing Industry

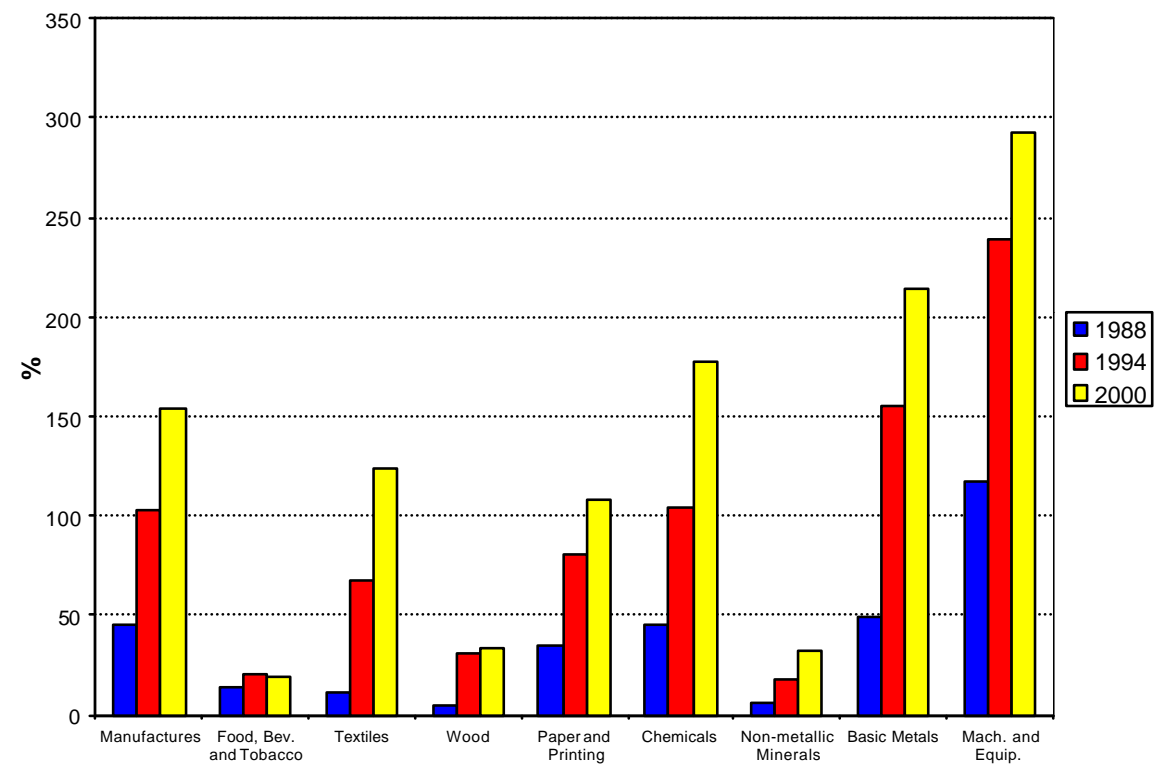

Together, both figures show the relevance that trade liberalization had on Mexico's foreign trade and domestic production, and, in consequence, they suggest that economic openness may also have had other important economy-wide effects including, of course, important effects on the labor market in general, and in real wages in particular. Let us review the evidence on wage inequality in Mexico in the recent past.

\section{Wage Inequality in Mexico}

There is ample evidence that wage inequality in Mexico has increased in the past two decades. ${ }^{13}$ Figure 3 shows the evolution of the wage ratio between production and nonproduction workers for Mexico's manufacturing industry between 1988 and 2000. If, as it is standard in the literature, we associate non-production workers with skilled workers and production workers with unskilled workers, this figure illustrates the increase in the wage gap between these types of workers that has also been reported in many other countries (Gottschalk and Smeeding, 1997 and IADB, 2002). ${ }^{14}$

\footnotetext{
${ }^{13}$ See, among others, Epelbaum and Cragg (1996) and Cortés (2001).

${ }^{14}$ Gonzaga et al. (2002) argue that the association between skill levels and types of job is not necessarily correct and that it may be misleading. They show that using the standard production/non-production workers' division suggests that wage inequality in Brazil has increased. However, if they use instead educational levels as a measure of skills, there is evidence that wage inequality in Brazil has fallen.
} 


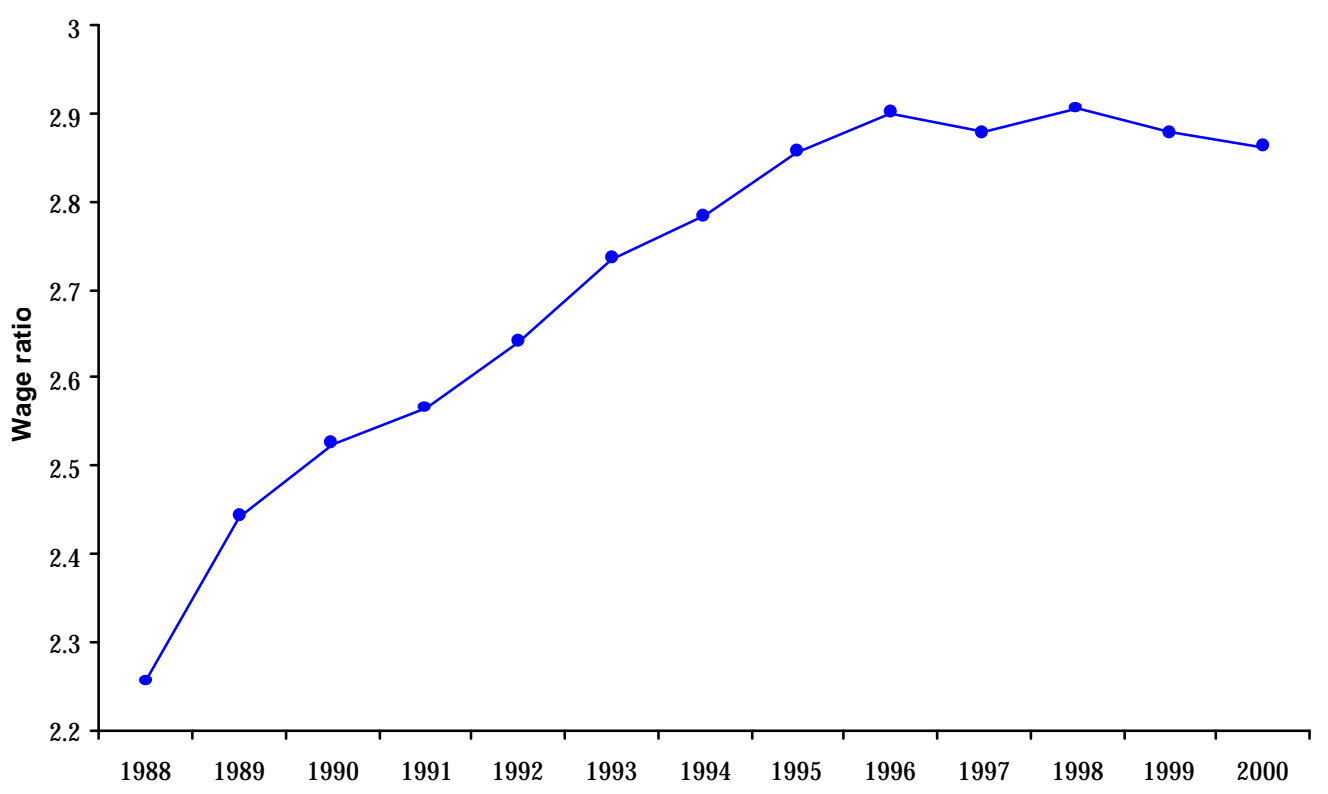

Figure 3 shows that the real average wage of non-production workers in Mexico's manufacturing industry was 2.25 times larger than the real average wage of production workers in 1988. This ratio increased monotonically between 1988 and 1996, when it was about 2.9, but since then it has remained practically stable, with two slight reductions in the last two years of the sample. Throughout the 1988-2000 period, the wage gap between skilled and unskilled workers real wages in Mexico increased by about $27 \%$.

A close look at Figure 3 suggests that the pattern of wage inequality until the mid1990s was different to that of the more recent years. Indeed, wage inequality in Mexico seems to have reached a plateau or it may have even begun a slow diminishing trend. Based on this observation, we split our sample in two different periods of the same length to see whether there is some evidence of a structural change in the pattern of wage inequality in Mexico. The periods that we will use are 1988-1994 and 1994-2000. This division is convenient since it captures the behavior of wage inequality in the periods before and after NAFTA. 
Figures 4 and 5 show the non-production/production wage ratio for the 49 branches of Mexico's manufacturing industry for different years. Figure 4 compares the observed wage ratio in 1988 (x-axis) with that of 1994 (y-axis), whereas Figure 5 does the same for the years 1994 and 2000. Both figures include a 45-degree line as a reference. Figure 4 shows that the increase in the wage gap between skilled and unskilled workers took place across-the-board in Mexico's manufacturing industry. ${ }^{15}$ In fact, the wage gap increased in 46 industries and diminished in only 3 industries. On the other hand, Figure 5 shows that the behavior of the wage gap at the branch level in the 1994-2000 period was completely different from that of the previous period. The figure shows that the wage ratio in 2000 was not consistently above or below its level in 1994 for the different branches of the manufacturing industry. In fact, approximately a half of the industrial branches show an increase in the skilled/unskilled wage ratio, whereas the other half shows slight reductions in the same indicator.

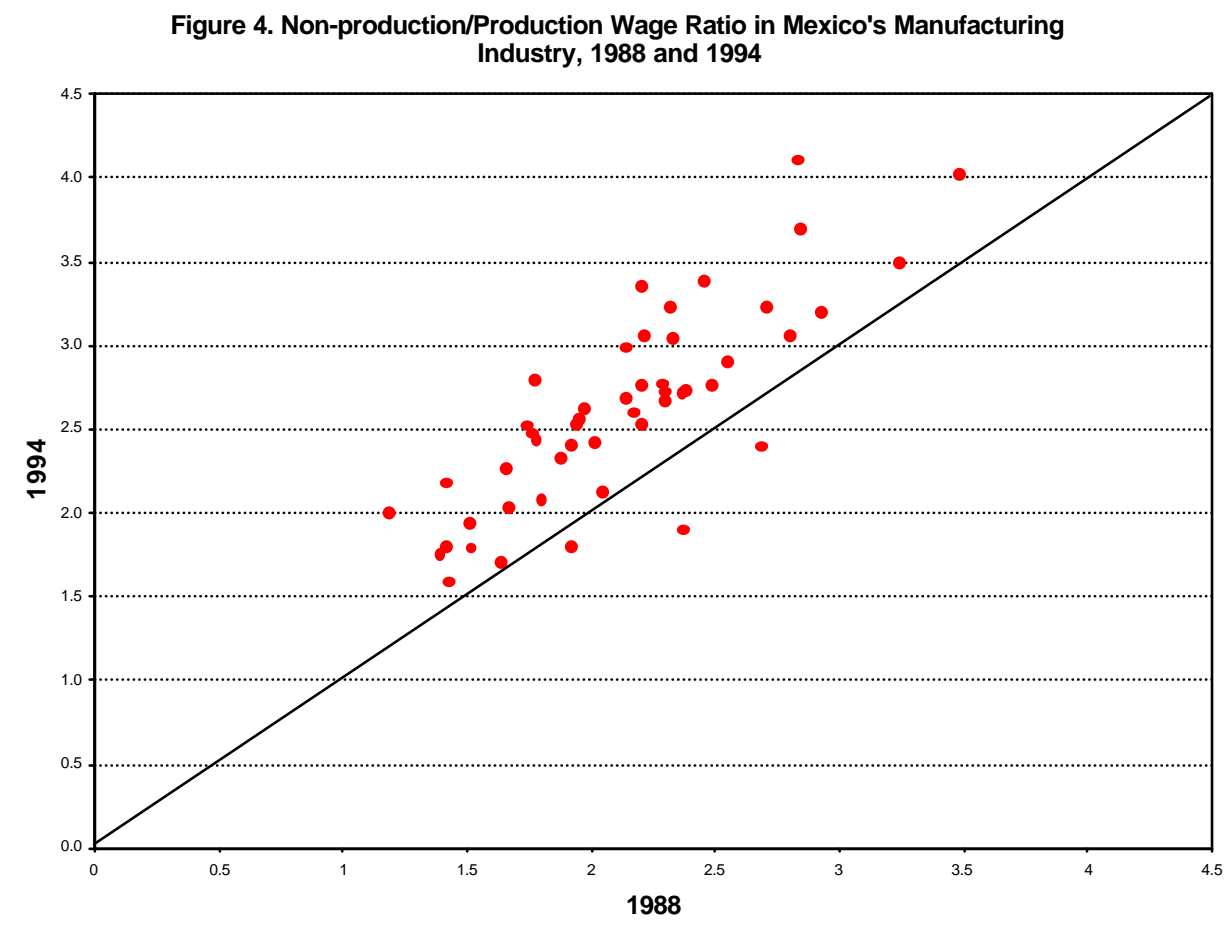

15 This generalized increase in wage inequality across industries was also found in Hanson and Harrison (1999) and Meza (1999). 


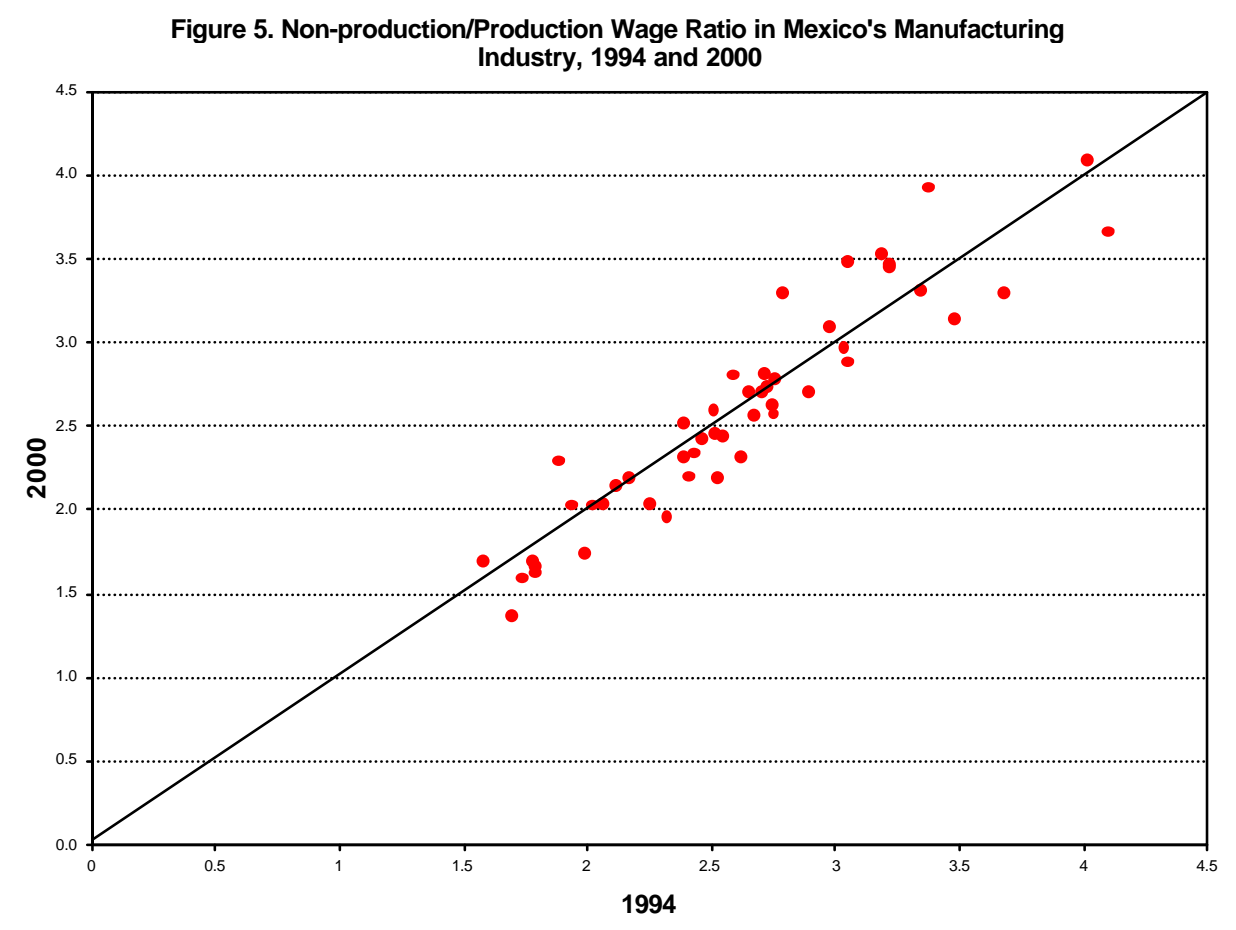

Figures 3-5 suggest that the behavior of the skilled/unskilled wage gap in Mexico followed different patterns in the periods before and after NAFTA. Of course, even if this is true, we cannot unambiguously conclude that this was a result of NAFTA. However, as it will be emphasized later, it is important to understand this stylized fact of wage inequality in Mexico.

On the other hand, it is also important to note that our data do not support the interpretation, advanced by Robertson (2001), that wage inequality in Mexico fell in the post-NAFTA period. ${ }^{16}$ Instead, our results show a slight increase in inequality when we look at the aggregate level, or a relatively stable skilled-unskilled wage ratio when we focus at the industry level. It is also important to mention that our results are compatible with the empirical evidence on the path of returns to education in Mexico shown in Meza (1999), Robertson (2001) and Cortés (2001), as well with the evolution of relative wages also shown in Robertson (2001). This difference cannot be overemphasized, since it will play an important role in the interpretation of our results and in our comparison with the previous empirical evidence.

\footnotetext{
16 This, in our opinion, incorrect interpretation, has been recently incorporated in several works. See, for example, IADB (2002), chapter 12.
} 


\section{Sources and determinants of wage inequality in Mexico. A Brief Survey.}

The facts described in the previous subsections imply that the relatively large increase in wage inequality in Mexico coincided with the program of trade liberalization started in the mid-eighties. As in many other countries, such a coincidence has led some authors to conclude that trade liberalization is responsible, at least partially, of such result (Robbins, 1997). In this part of the paper, we review some of the empirical evidence on the sources and determinants of wage inequality in Mexico, as well as its relationship with trade and technological aspects.

The empirical evidence on the determinants of wage inequality in Mexico can be roughly divided in two groups. On the one hand, some authors analyze the immediate causes of an increase in wage inequality, namely, the evolution of returns to skills or, its proxy, returns to education. This is the case of Epelbaum and Cragg (1996), Meza (1999), Cortés (2001), and Airola and Juhn (2001). On the other hand, there are a number of authors that study what could be the ultimate causes of the increase in wage inequality. In particular, they have mainly focused on the possible role of trade and technology as determinants of such pattern. This is the case of Hanson and Harrison (1999), Robertson (2001), Cañonero and Werner (2002), and Meza (2003).

The first group of papers has shown that in the past two decades there has been an important increase in the skill premium in Mexico. Epelbaum and Cragg (1996), for example, showed that between 1987 and 1993 the wages of Mexican workers with more experience and more education grew faster than those of workers with lower levels of experience or education. Epelbaum and Cragg conclude that the generalized increased in the skill premium across industries rules out several possible interpretations (supply side, trade, etc.) and that it only leaves technological change as a plausible explanation of the observed trend in the skill premium in Mexico.

On the other hand, Meza (1999) and Cortés (2001) have documented the recent increase in the returns to education in Mexico. Meza (1999) analyzed the case of urban 
workers in Mexico between 1987 and 1993, whereas Cortés (2001) studied the case of urban male workers in Mexico between 1984 and 1996. In the more recent and updated paper in this line, Airola and Juhn (2001) show that returns to post-secondary schooling in Mexico increased sharply between 1984 and 1994, but that they remained almost unchanged between 1994 and 1998. This result is consistent with the empirical evidence presented in our figures 4 and 5 and with the results obtained by Calmon et al. (2000).

Regarding the second line of research, Hanson and Harrison (1999) analyze the sources of wage inequality in Mexico by looking at the employment composition between and within industries. They argue that since most of the employment adjustment in the 1984-90 period occurred within industries, therefore we cannot conclude that there is a trade channel that may explain this result. ${ }^{17}$ Assuming that Mexico was a skilled labor abundant country (relative to the world), Hanson and Harrison rule out the existence of Stolper-Samuelson effects and they report that there is only weak evidence in favor of the technological hypothesis. They suggest that unskilled labor wages diminished because trade barriers tended to protect industries intensive in this type of labor.

Cañonero and Werner (2002) study the widening of wage differentials between skilled and unskilled workers in Mexico after the trade liberalization process in Mexico. They attempt to explain why unskilled wages fell 20 percent relative to skilled wages in the aftermath of the liberalization period (between 1986 and 1990). They argue that this apparently counterintuitive result is explained because the Stolper-Samuelson theorem works only in the long run, whereas in the short run other factors may be at work. Among other aspects, the authors mention that capital goods prices fell after liberalization. If capital and skilled labor are complements in production, this reduction in prices could have induced greater demand for skilled workers and thus raising the wage gap between skilled and unskilled wages.

On the other hand, Robertson (2001) analyzes the behavior of relative prices and wage inequality in Mexico between 1987 and 1999. According to him, wage inequality in

\footnotetext{
${ }^{17}$ Meza (1999) found a similar result. See also the results in Epelbaum and Cragg (1996).
} 
Mexico rose after its accession to GATT and began to diminish after the implementation of NAFTA. Robertson argues that this pattern was not completely unexpected since the entrance to GATT implied that Mexico opened its frontiers to countries that, in relative terms, are more abundant in unskilled labor, whereas entrance to NAFTA implied exactly the opposite pattern because then Mexico opened its economy to countries that are more skilled labor abundant such as Canada and the United States. Robertson presents empirical evidence suggesting that the relative price of skill-intensive goods rose after GATT and diminished after NAFTA, which seems consistent with the predictions of the StolperSamuelson theorem.

As mentioned before, there are at least two problems with Robertson's results. First, most of the empirical evidence on wage inequality is not consistent with the facts that he is trying to explain. If anything, Mexico's wage inequality (or, for that matter, either returns to skills or education) has remained unchanged after NAFTA, and there is no evidence of a reduction in the wage gap between skilled and unskilled labor in Mexico after 1994. ${ }^{18}$ Second, the reduction of Mexico's trade barriers in the mid-eighties was with respect to all countries. This means that Mexico opened its economy in the mid-eighties not just to more unskilled labor abundant countries but also to all developed countries, and this includes, of course, Canada and the United States. Indeed, it is important to mention that Mexico's foreign trade is highly concentrated (and it has become more so in the recent years) in the United States and other developed countries. Indeed, more than 93\% of all Mexican foreign trade takes place with United States, Canada, European countries and Japan, whereas only about $2 \%$ of total Mexican external trade occurs with poor countries. For example, as recent as 1994, Mexico's imports from China were only about $0.5 \%$ of total imports, and $\mathfrak{t}$ has not been until the late 1990s that imports from China have started to increase in a significant manner. ${ }^{19}$ Therefore, the hypothesis that Stolper-Samuelson effects on Mexico's relative wages should have gone in the directions suggested by Robertson is untenable.

\footnotetext{
${ }^{18}$ See, for instance, figures 1b, 2, and 3 in Robertson (2001), as well as Airola and Juhn (2001).

${ }^{19}$ It could still be argued that Mexico competes with countries like China and India in third markets. Although this could be true, it is clear that in the determination of local relative wages the volume of trade with this type of countries should also matter. This point has also been emphasized by Krugman (2000).
} 
Finally, Meza (2003) analyzes changes in Mexico's manufacturing labor market between 1988 and 1998. Using indirect estimations of the effect of trade liberalization and technological change on the relative employment and wage structure in Mexico's manufacturing industry, she finds that changes in the latter have been mostly driven by technological change rather than by trade liberalization. She also reports results suggesting that the increase in Mexican exports has benefited low-skilled workers, as would be expected if we accept that Mexico is abundant on this factor.

In summary, there is no definitive evidence on the role of trade and technology in explaining wage inequality in Mexico and there is no agreement on the validity of the Stolper-Samuelson predictions for the Mexican case. On the one hand, some authors conclude that external trade explains the pattern of wage inequality in Mexico, whereas other authors suggest that technological change is the main force driving this variable. On the other hand, some authors suggest that the Stolper-Samuelson predictions could explain the observed pattern of wage inequality in Mexico as long as we are willing to assume that Mexico is not unskilled labor abundant, while others suggest that the Stolper-Samuelson implications are expected to occur only in the long run. Yet other authors suggest that the empirical evidence is indeed compatible with the standard predictions of the theorem. In the next section we will try to contribute to this debate. 


\section{Methodology and Data}

We are interested in separating out the effects of technology and trade on the evolution of real skilled and unskilled wages in Mexico. In order to achieve that objective, we will follow the "mandated wage" approach suggested by Leamer (1998). Krueger (1997) and Baldwin and Cain (2000) have used a similar methodology for the case of the United States. $^{20}$

The "mandated wage" approach is particularly interesting in this case because, as suggested by Slaughter (2000), it is the most appropriate way of testing the correlation version of the Stolper-Samuelson theorem, and this version, according to him and others, is the one that relates more clearly trade with wage inequality. The correlation version of the Stolper-Samuelson theorem states: "For any vector of goods price changes, the accompanying vector of factor price changes will be positively correlated with the factor intensity-weighted averages of the goods price changes" (Slaughter, 2000). This means that if we are interested in analyzing the evolution of real wages of different factors, we may exploit the association that should exist between these and the goods prices through the different factor intensities used in the production process.

\section{The mandated wage approach}

This approach underscores the fact that in all competitive industries product prices and factor prices must be linked through a set of "zero-profit conditions". These conditions may be written as:

$$
\mathrm{P}=\mathrm{A} \cdot \mathrm{W}
$$

where $\mathrm{P}$ is a vector of $\mathrm{N}$ domestic prices, $\mathrm{W}$ is a vector of $\mathrm{M}$ domestic factor prices and $\mathrm{A}$ is a $(\mathrm{N} \times \mathrm{M})$ matrix whose elements indicate the number of units of different factors needed to produce the different products. It is important to emphasize that these equations imply

\footnotetext{
${ }^{20}$ Feenstra and Hanson (1999) have recently suggested a variation on this methodology. See also Haskel and Slaughter (2001) for an application to the UK.
} 
that product prices equal average costs (zero-profits) and that factor prices are assumed to be the same across industries (i.e., we assume interindustry factor mobility).

For sufficiently small changes, and allowing for changes in total factor productivity and for intermediate goods, we can rewrite equation (1) as

$$
\hat{P}=\boldsymbol{\theta} \cdot \hat{w}-\gamma \cdot \hat{P}-T \hat{F P}
$$

where $\hat{P}$ is a vector of $\mathrm{N}$ domestic product-price changes, $\hat{w}$ is the vector of $\mathrm{M}$ domestic factor price changes, $\theta$ is an initial cost-share matrix whose elements tell us the share of different factors in the average cost needed to produce one unit of the different products, $\gamma$ is an input shares matrix, and $T \hat{F P}$ is a vector of total factor productivity growth in the $\mathrm{N}$ industries.

If we assume a price-taking economy, equation (1) implies that changes in productivity cannot affect either final product prices or value-added prices. ${ }^{21}$ Therefore, from (1) we obtain what Leamer has named "technological effect on wages" as:

$$
T \hat{F P}=\boldsymbol{\theta} \cdot \hat{w}(t)
$$

Given the initial matrix $\theta$, this equation tells us the "mandated" wage changes $(\hat{w}(t))$ that are due to productivity improvements (or technological change) and that are compatible with the assumption of both, a price-taking economy and a zero-profit condition.

After allowing for the effect of technological progress on prices, what is left on product price changes can now be attributed to trade liberalization or "globalization" effects:

$$
\hat{p}_{i}=\boldsymbol{\theta}_{i}^{\prime} \cdot \hat{w}(g)+\gamma_{i}^{\prime} \hat{p}
$$

where $\hat{p}_{i}$ is good $i$ 's price growth, $\gamma_{i}$ is the vector of materials inputs' shares in good $i$ 's price, $\hat{p}$ is the vector of prices and $\hat{w}(g)$ is the vector of mandated changes in factor prices

\footnotetext{
${ }^{21}$ In the original model, Leamer assumes that TFP may only affect value-added prices through a factor $\lambda$. This is his pass-trough assumption (see equation 3 in Leamer, 1998). We are implicitly assuming that $\lambda=0$, as corresponds to a price-taking economy.
} 
not due to productivity improvements and that are compatible with the zero-profit and price-taking economy assumptions.

Equations (3) and (4) can be implemented empirically by pooling information at the industry level and then estimating two separate regressions:

$$
\begin{gathered}
T \hat{F} P_{i t}=\theta_{i t}{ }^{\prime} \beta_{T}+\varepsilon_{i t} \\
\hat{p}_{i t}-\gamma_{i}{ }^{\prime} \hat{p}_{t}=\theta_{i t}{ }^{\prime} \beta_{T L}+\eta_{i t}
\end{gathered}
$$

In equations (5) and (6), $\gamma$ is the observed value of material inputs' shares in good $i$, whereas $\beta_{T}$ and $\beta_{T L}$ are the "mandated" factor price changes due to technological change and trade liberalization (or globalization), respectively. These factor changes are those that are consistent with keeping zero profits in all sectors.

As Slaughter (2000) has pointed out, the entire mandated wage approach should be seen as an accounting exercise that checks the consistency of the assumptions, rather than as an exercise of identifying causation between variables. This is so because unlike standard regression analysis, here the exogenous variables are the dependent variables, while the dependent variables of interest (factor price changes) are estimated. We proceed in this manner because the matrix $\theta$ is not squared (we have more products than factors) and therefore it is not invertible. Note that this also precludes us from analyzing two or more exogenous forces in the same regression, and that is why we should estimate separate regressions for each effect.

Before proceeding to dscuss the data and the empirical evidence, a word of caution about the interpretation of the effects is in order. So far, we have followed Leamer (1998) in referring to parameters in equations (5) and (6) as "technological effect" and "globalization effect", respectively. However, it must be said that the "technological effect" is just a proxy for that. In reality, this estimate is meant to capture the factor price changes that would occur as a result of productivity improvements and, even if productivity reflects technological change relatively well, this effect will correctly represent the technological effect only as long as the economy takes prices as given. Similarly, the "globalization 
effect" in reality means the mandated factor price changes that ccur as a result of factors other than productivity improvements. This definition means that the "globalization effect" captures anything else that affects factor prices other than productivity and that is consistent with the zero-profit condition. For example, this effect will capture macroeconomic shocks as well as other industry-wide effects. More important, however, is the fact that, at least in the case of developing countries, we cannot really separate out technological change from globalization. Indeed, as has been suggested by many authors, technological change or increases in productivity in developing countries are strongly associated to the opening of the economy (Robbins, 1996a and Feenstra and Hanson, 1996). In many cases, technology adoption and productivity improvements are mostly due to greater competition from the rest of the world whereas, in other cases, they are associated to the presence of foreign direct investment. In that sense, technological change in a developing country can ultimately be related to "globalization". Despite this consideration, we believe that it is still interesting to estimate equations (5) and (6) for the Mexican case. However, we need to be very careful with the interpretation and meaning of the estimated effects. In particular, hereafter we will prefer not to use the term "globalization effect". Instead, we will use the term "trade liberalization effect", although we are aware that it captures many other effects and not just those related to trade liberalization. As stated before, this effect captures anything else that is not directly caused by productivity improvements.

\section{Data}

We collect annual data for 49 branches of Mexico's manufacturing industry for the period 1988-2000. Most of our data come from the National Accounts System, where there is information about shares of the factors of production and materials inputs, annual growth of labor productivity, annual growth of material inputs' prices and annual growth of the average product price of each manufacturing branch. This dataset also has information on production and non-production workers' wages at the industry level.

Instead of calculating TFP at the branch level, we prefer to use the labor productivity information calculated by INEGI. Using this measure, allows us to avoid all 
the associated problems in estimating TFP at the industry level when there is no good information on capital stocks by industry. Using labor productivity as a proxy for TFP changes is also useful since there is evidence that labor productivity in Mexico is highly correlated with TFP improvements at the industry level (see Easterly et al. (2003)). Besides, it precludes us from incurring in the identification problems mentioned by Feenstra and Hanson (1999). In that sense, the labor productivity measure that we use plays a role similar to that of an instrumental variable in a standard regression analysis.

\section{Empirical Results}

Based on the intuition provided by Figures 4 and 5, we have divided our analysis in two sub-periods: 1988-94 and 1994-00. The goal of such division is twofold: first, to capture the differentiated pattern in the wage gap that occurred in both periods. Second, because this division neatly separates our sample in two periods of similar size that coincide with the before and after-NAFTA periods.

We estimated empirically equations (5) and (6) using pooled time-series crosssection data for 49 branches of Mexico's manufacturing industry. ${ }^{22}$ To reduce problems associated to year-specific shocks, we use biannual information (1988-90, 1990-92 and so on). That is, every sub-period of analysis includes information for 49 branches and 3 time observations, a total of 147 observations per period. ${ }^{23}$

Table 2 shows the results of our first estimates of equations (5) and (6). In this case, we use three factors of production: capital, production and non-production workers. As it is standard in the literature, we associate production workers with unskilled labor and nonproduction workers with skilled labor. All the estimated equations fit the data relatively

\footnotetext{
22 It is important to note that we are not the first authors that apply the mandated wage approach to Mexican data. Robertson (2001) has recently estimated regressions similar to the ones that we present below. His results, however, are far from conclusive. Robertson failed to reach a conclusion based on his analysis for at least two reasons: first, because his estimates were very imprecise (almost none of the implied wage changes was statistically significant); and second, because his results changed dramatically once he included intermediate material and technological change into the equations.

${ }^{23}$ Note that as a result of the relatively short size of the sample along the time dimension, we cannot estimate panel data models that allow for industry fixed or random effects.
} 
well and most coefficients are statistically significant. To obtain "mandated" real factor price changes we need to adjust our coefficients in equation (6) by domestic inflation.

Table 3 shows the mandated annual changes in both real wages and in the wage gap between production and non-production workers. This table shows results that are at odds with the observed trend in wage inequality. On the one hand, our results show that the implied change in the wage gap in the first period was negative, suggesting that wage inequality should have fallen; whereas the opposite should have occurred in the postNAFTA period. Indeed, in both periods technological and trade liberalization effects reinforced each other in order to generate these predictions. As discussed before, none of these situations actually happened. Therefore, judging our results by the compatibility of our implications with the observed patterns (as Leamer, 1998, and Slaughter, 2000 suggest that we should do), we can conclude that this specification does not provide convincing results.

\begin{tabular}{|l|cc|cc|}
\hline \multicolumn{5}{|c|}{ Table 2. M andated Waqe Equations with Production and N on-production Workers } \\
\hline & \multicolumn{2}{|c|}{ Equation (5) } & \multicolumn{2}{c|}{ Equation (6) } \\
& $1988-1994$ & $1994-2000$ & $1988-1994$ & $1994-2000$ \\
\hline Production workers & 0.256 & -0.315 & 0.097 & 0.363 \\
& $(0.021)$ & $(0.031)$ & $(0.056)$ & $(0.094)$ \\
N on-production workers & -0.164 & 0.430 & -0.147 & 0.694 \\
& $(0.057)$ & $(0.032)$ & $(0.064)$ & $(0.120)$ \\
Capital & & & & \\
& 0.096 & 0.079 & 0.158 & 0.053 \\
& $(0.010)$ & $(0.005)$ & $(0.017)$ & $(0.029)$ \\
\hline R squared & & & & \\
F-statistic & 0.95 & 0.97 & 0.76 & 0.43 \\
S.E. of regression & 1493.1 & 2577.4 & 155.2 & 55.1 \\
Observations & 0.071 & 0.047 & 0.039 & 0.051 \\
& 147 & 147 & 147 & 147 \\
\hline
\end{tabular}

N otes: H eteroskedasticitv-consistent standard errors in parentheses. Bolded coefficients are statistically significant at the $5 \%$ level. 


\begin{tabular}{|l|c|c|cc|cc|}
\hline \multicolumn{7}{|c|}{ Table 3. "M andated" annual growth in real wages and in the wage gap } \\
\hline & Trade Liberalization Effect & Technological Effect & \multicolumn{3}{c|}{ Total } \\
Production workers & $1988-1994$ & $1994-2000$ & $1988-1994$ & $1994-2000$ & $1988-1994$ & $1994-2000$ \\
Non-production workers & -0.059 & 0.147 & 0.256 & -0.315 & 0.196 & -0.169 \\
Capital & -0.303 & 0.478 & -0.164 & 0.430 & -0.467 & 0.908 \\
& 0.001 & -0.163 & 0.096 & 0.079 & 0.097 & -0.085 \\
Wage G ap (non-production/production workers) & -0.244 & 0.332 & -0.420 & 0.745 & -0.663 & 1.077 \\
\hline
\end{tabular}

Table 3 shows other results that do not seem coherent or logic. For example, our estimates suggest that the technological effect seems to have operated in different directions in the pre and the post-NAFTA periods, which does not seem consistent with the empirical evidence on this regard. Also, trade liberalization effects also operated in different directions on the wage gap in both periods, but they operated in the exact opposite direction of that suggested by Robertson (2001).

Results in Tables 2 and 3 could be interpreted as a rejection of the entire "mandated" wage approach. However, it may still be the case that there are problems in using an association as simple as that between production/non-production workers with unskilled/skilled workers. In fact, many economists have questioned the division of labor in production and non-production workers as a proxy to the workers' skill level. ${ }^{24}$ It is often argued that there is a significant proportion of production workers who are skilled and, equivalently, an important proportion of non-production workers who are unskilled.

In Table 4 we illustrate this point for the manufacturing industry in Mexico. In this table we present descriptive satistics of the average nominal wages for production and nonproduction workers for the years 1988 and 2000. As expected, the average wage of nonproduction workers is well above the average wage of production workers in both years. However, in both years the minimal values of both categories are not statistically different. This suggests that there is a segment of the wage distribution where production and nonproduction wages overlap each other. In principle, if skilled labor is clearly identifiable

24 See, for example, Leamer (1994). Gonzaga et al. (2002) show, for the Brazilian case, how the production/non-production classification may lead to erroneous conclusions. 
from unskilled labor, then we should observe a clear separation between skilled and unskilled wages. Since this is not the case when using the production/non-production classification, then we may conclude that this division is not necessarily appropriate.

\begin{tabular}{|l|cc|cc|}
\hline \multicolumn{6}{|c|}{ Table 4. A verage wages at current prices (in thousands) } \\
\hline \multirow{4}{*}{} & \multicolumn{2}{|c|}{$\mathbf{1 9 8 8}$} & \multicolumn{2}{c|}{ 2000 } \\
\cline { 2 - 6 } & $\begin{array}{c}\text { Production } \\
\text { workers }\end{array}$ & $\begin{array}{c}\text { N on-production } \\
\text { workers }\end{array}$ & $\begin{array}{c}\text { Production } \\
\text { workers }\end{array}$ & $\begin{array}{c}\text { N on-production } \\
\text { workers }\end{array}$ \\
\cline { 2 - 6 } M ean & 7.56 & 15.62 & 70.47 & 177.74 \\
M edian & 6.37 & 14.17 & 57.41 & 170.60 \\
M inimum & 20.25 & 38.82 & 279.50 & 611.42 \\
Std. D ev. & 3.39 & 4.72 & 24.48 & 38.79 \\
Observations & 3.70 & 7.05 & 42.89 & 98.21 \\
Source: National Accounts System, INEGI. & 49 & 49 & 49 \\
\hline
\end{tabular}

To address this issue, we proceed to construct, through an extrapolation mechanism suggested by Leamer (1998, Table 5), a new classification of workers between low wage earners and high wage earners. The intuition is that wage differences across sectors come only from differences in the skilled/unskilled mixes of workers. It is then assumed that the sector with the lowest average wage uses only unskilled labor (and this defines the low wage level), whereas the sector with the highest average wage has only skilled labor (thus defining the high wage level). Based on these assumptions we extrapolate the proportion of high and low wage workers in each sector, assuming that each type of worker perceives the same wage across sectors. We do this for both production and non-production workers, and we pooled our results in two groups, low wage and high-wage workers. As it is natural, we will associate low wage earners with unskilled labor and high wage earners with skilled labor.

Using this extrapolated data, the skilled/unskilled wage ratio follows a similar pattern to that described in Figure 2, except for the fact that the wage ratio between 1988 and 1994 now increased by as much as $90 \%$ (i.e. at an annualized rate of $11.3 \%$ ), whereas 
the wage ratio between 1994 and 2000 increased only in about 10\% (i.e. slightly above $1 \%$ per year). ${ }^{25}$

Table 5 shows the results of our estimates of parameters in equations (5) and (6) when using our extrapolated data, whereas Table 6 shows the corresponding "mandated" changes in real factor prices as well as in the wage gap. It is worth emphasizing that all estimated coefficients in Table 5 are statistically significant. But, more importantly, we should stress that results in these two tables seem to be relatively consistent with the observed patterns in real factor prices as well as with conventional theoretical predictions. Let us review these results in more detail.

\begin{tabular}{|l|cc|cc|}
\hline \multicolumn{5}{|c|}{ Table 5. M andated wage Equations with Low and High Wage Workers } \\
\hline & \multicolumn{2}{|c|}{ Equation (5) } & \multicolumn{2}{c|}{ Equation (6) } \\
& $1988-1994$ & $1994-2000$ & $1988-1994$ & $1994-2000$ \\
& & & & \\
\hline Low wage workers & -0.209 & -0.171 & 0.259 & 0.115 \\
& $(0.089)$ & $(0.020)$ & $(0.056)$ & $(0.030)$ \\
& & & & \\
High-wage workers & 0.247 & 0.190 & -0.064 & 0.129 \\
& $(0.050)$ & $(0.016)$ & $(0.030)$ & $(0.031)$ \\
Capital & & & & \\
& 0.070 & 0.049 & 0.170 & 0.095 \\
& $(0.020)$ & $(0.002)$ & $(0.012)$ & $(0.009)$ \\
\hline R squared & & & & \\
F-statistic & 0.235 & 0.766 & 0.758 & 0.982 \\
S.E. of regression & 22.1 & 235.9 & 225.3 & 2550.1 \\
O bservations & 0.066 & 0.047 & 0.037 & 0.030 \\
& 147 & 147 & 147 & 147 \\
\hline
\end{tabular}

N otes: H eteroskedasticity-consistent standard errors in parentheses. Bolded coefficients are statistically significant at the $5 \%$ level. Regression used cross-section weights. Regressions for 1994-2000 include a dummy for the first biannual period.

25 The magnitudes of these results are compatible with the empirical evidence on returns to education or returns to skill classified by occupation. See Meza (1999), Calmon et al. (2000), and Cortés (2001). 


\begin{tabular}{|c|c|c|c|c|c|c|}
\hline \multicolumn{7}{|c|}{ Table 6. "M andated" annual growth in real wages and in the wage gap } \\
\hline & \multicolumn{2}{|c|}{ Trade Liberalization Effect } & \multicolumn{2}{|c|}{ Technological Effect } & \multicolumn{2}{|c|}{ Total } \\
\hline & 1988-1994 & 1994-2000 & 1988-1994 & 1994-2000 & 1988-1994 & 1994-2000 \\
\hline Low wage workers & 0.103 & -0.101 & -0.209 & -0.171 & -0.107 & -0.272 \\
\hline High wage workers & -0.220 & -0.085 & 0.247 & 0.190 & 0.027 & 0.106 \\
\hline Capital & 0.013 & -0.121 & 0.070 & 0.049 & 0.084 & -0.073 \\
\hline G ap Wage (high wage/low wages) & -0.323 & 0.016 & 0.457 & 0.362 & 0.134 & 0.378 \\
\hline
\end{tabular}

In terms of the implied change of real factor prices, it is interesting to note that the technology effect was quite consistent across periods and that it followed the expected pattern. This means that technological change implied a reduction in the real wages of unskilled workers and an increase in the real price of skilled workers in both periods. In that sense, technological change in the 1988-2000 period has pressed for an increase in the wage gap between skilled and unskilled workers. This result is consistent with previous empirical evidence on Mexico (see Cragg and Epelbaum, 1996, and Meza, 1999). Also, in a parallel manner, and consistent with our priors, technological change has also induced an increase in the real price of capital in both periods.

On the other hand, the trade liberalization effect operated in the opposite direction of the technology effect in the first period, and was close to zero in the second period. That is, trade liberalization pressed for a substantial reduction in the wage gap between skilled and unskilled workers in the first period. Indeed, in this period, a reduction in the wage gap could have occurred since trade liberalization induced an increase in the real wage of unskilled workers and a reduction in the real wage of skilled workers (exactly as predicted by the Stolper-Samuelson theorem). In the post-NAFTA period, the trade liberalization effect implied an equivalent reduction in the real wages of both types of workers. ${ }^{26}$ This means that trade liberalization after NAFTA has implied a constant wage gap between skilled and unskilled workers. In any event, a very important result in Tbale 6 is that the

\footnotetext{
${ }^{26}$ It must be taken into account that the trade liberalization effect includes all other effects different from technology that are compatible with the zero-profit and price taking assumptions. In that sense, the implied reduction in both real wages in the 1994-00 could only be capturing the medium-term effects of the crisis that affected the Mexican economy in 1995.
} 
trade liberalization effect operated in at least one period in the way that is predicted by the standard trade theory. That is, since Mexico is an unskilled labor abundant country relative to its main trade partners, then it is natural to expect that trade liberalization should have led to an increase in the relative price of the abundant factor, and this in turn should have reduced the wage gap between skilled and unskilled labor. This is precisely what our results show for the pre-NAFTA years.

As had been speculated by many authors before (Epelbaum and Cragg, 1996, Meza, 1999; Cañonero and Werner (2002), and others), there was something else going on in the Mexican economy that precluded the Stolper-Samuelson effects from showing up in the data. This other effect was precisely the presence of a contemporaneous technological change that was pressing in exactly the opposite direction. This result is shown in the last column of Table 6, where it shows the "mandated" changes in real wages that result fom combining both effects. In the pre-NAFTA period, the implied reduction in wage inequality due to the trade liberalization was more than compensated by the implied increase in wage inequality due to technological change. In fact, the total "mandated" wage gap change in the first period was around $13 \%$ per year, which is very close to the observed increase of more than $11 \%$ per year (see Figure 6). It is important to note that our results for ethe firs period are consistent with the prediction of Cañonero and Werner (2002) in the sense that observed changes mask important movements in the underlying factors affecting the behavior of real wages, because they tend to move in opposite directions.

Finally, in the post-NAFTA period, the implied changes in wage inequality due to trade liberalization were close to zero, but the implied change in the wage gap due to the technological change were very large (see Figure 6). This means that the total "mandated" change in the wage gap was also large, which is not quite compatible with the relatively small increase in the wage gap that was observed in Mexico in the post-NAFTA period. In any event, it is important to stress that the mandated wage methodology suggested by Leamer (1998) produces results that are relatively in line with the observed changes in the real wages in Mexico. 
Figure 6. "Mandated" Annual Growth in the Wage Gap (High Wage/Low Wage)

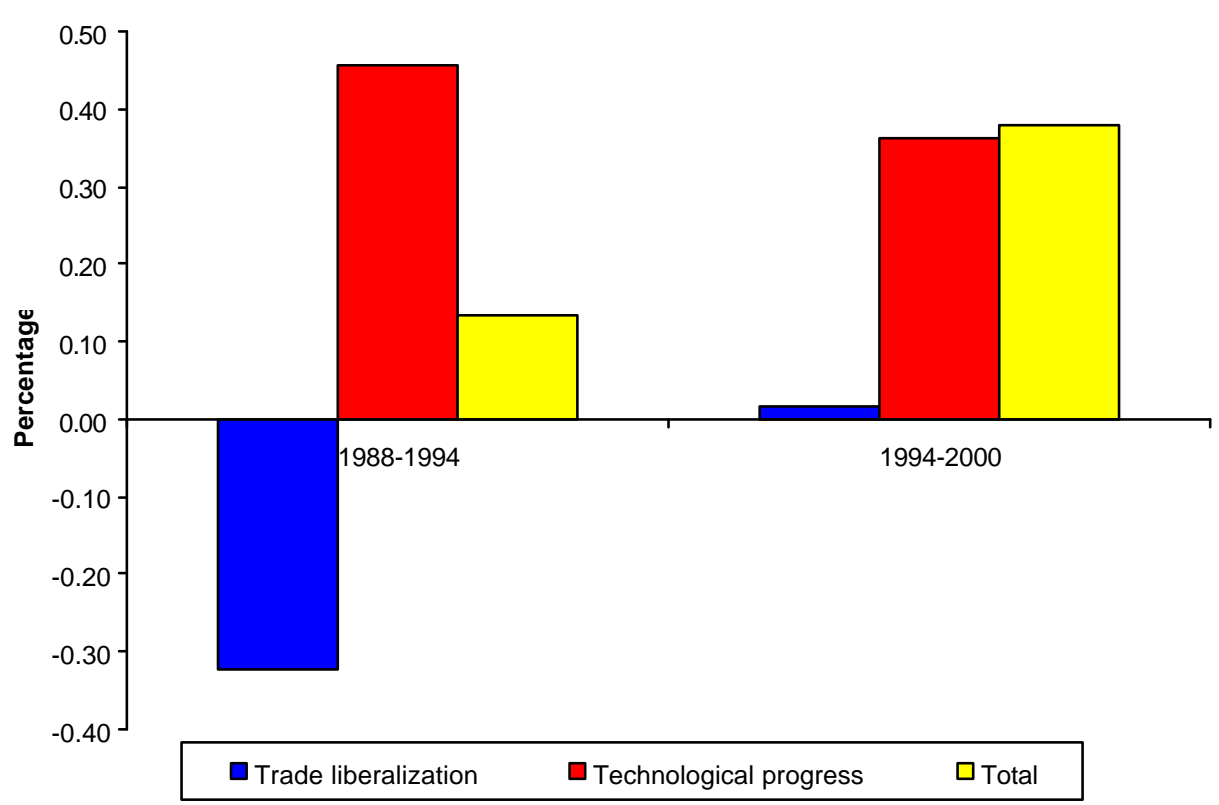

\section{Conclusions}

Wage inequality in Mexico increased sharply after 1980 and until the mid-nineties, and it has remained almost unchanged since then. The fact that the increase in wage inequality coincided with the period of trade liberalization was puzzling since most people considered Mexico as an unskilled labor abundant country, and the predictions of the conventional trade theory for these type of countries was that a reduction in trade barriers should led to a reduction in the wage gap between skilled and unskilled workers (Stolper-Samuelson theorem). The lack of coherence between theory and reality, led many authors in search of an explanation for such a paradoxical result.

There were many different approaches and lines of research to address the issue. On the one hand, some authors, based on simple correlations between trade liberalization and wage inequality, suggested that something could be wrong with the theoretical models. Other authors, more creative, developed convoluted explanations to suggest that the theory was right but that Mexico was in reality a skilled labor abundant country. Of course, this line of reasoning could explain now reasonably well why wage inequality in Mexico increased in the aftermath of trade liberalization. However, the assumption that Mexico is a 
skilled-labor abundant country is difficult to sustain and the story has problems in explaining the recent stability in the wage gap in Mexico. Other authors, more cautious, suggested that there could be something else going on. In particular, several authors suggested the possibility of a skill-biased technological change or a generalized increase in the demand of skilled labor in Mexico. Indeed, several authors found direct and/or indirect evidence in favor of the hypothesis that technological change could be playing an important role in explaining the observed trends in wage inequality in Mexico. Despite this evidence, there were still doubts about the validity of the predictions of the theoretical models, as well as of the relative importance of trade and technological factors in explaining the observed pattern of wage inequality in Mexico.

In this paper we have applied the "mandated" wage approach suggested by Leamer (1998) to separate out the effects of trade and technology in wage inequality in Mexico before and after NAFTA. Our results show that, as suspected, technology was responsible for the sharp increase in wage inequality in Mexico in the pre-NAFTA period. In that sense, our results are consistent with previous findings by Cragg and Epelbaum (1996), Cañonero and Werner (2002), and Meza (1999, 2003). More importantly, however, is that our results show that the effect of trade liberalization in the pre-NAFTA period was exactly in the direction predicted by the Stolper-Samuelson theorem under the assumption that Mexico is an unskilled labor abundant country (as surely it is, at least compared to its main trade partners). That is, in absence of technological change, trade liberalization would have led to a reduction in the wage gap in Mexico in both periods. In the first period, however, the effects of technological change on the wage gap more than compensated the trade liberalization effects, therefore leading to the observed increase in wage inequality. In the post-NAFTA period, the effect of rade liberalization on the wage gap was almost zero, but technological change again pressed for an increase in the wage gap. In this case, however, the magnitude of the increase in the wage gap mandated by the technological change clearly exceeded the observed increase in the wage gap in Mexico. This is an issue that deserves to be explored further. 
In sum, our results for Mexico show strong support for the predictions of the Stolper-Samuelson theorem in the pre-NAFTA period, and also for the hypothesis that there has been a generalized technological change that has pressed for an increase in the returns to skills. These two effects work in opposite directions in developing countries and the observed pattern of wage inequality will depend on the relative magnitude of both effects. 


\section{References}

Ailero, J. and C. Juhn (2001); "Wage Inequality in Post-reform Mexico", mimeo, Houston University.

Baldwin, R. and G. Cain, G. (2000). "Shifts in Relative U.S. Wages: The Role of Trade, Technology and Factor Endowments." Review of Economics and Statistics, 82(4), November, 580-595.

Berman, E., J. Bound and S. Machin (1998), "Implications of Skill-biased Technological Change: International Evidence", Quarterly Journal of Economics, 113, 1245-80.

Beyer, H., P. Rojas and R. Vergara (1999) "Trade Liberalization and Wage Inequality". Journal of Development Economics, 59(1), June, 103-123.

Bhagwati, J. (1995), "Trade and Wages: Choosing among Alternative Explanations", Economic Policy Review, Federal Reserve Bank of New York, January, 42-47.

Calmon, P., P. Conceição, J. K. Galbraith, V. Garza-Cantu and A. Hibert (2000), “The Evolution of Industrial Wage Inequality in Mexico and Brazil: a Comparative Study," Review of Development Economics, 4(2): 194-203.

Cañonero, G. and A. Werner (2002); "Salarios Relativos y Liberalización del Comercio en México”, El Trimestre Económico, Vol. LXIX, no. 273, pp. 123-142.

Cortes, W. (2001), "What is Behind Increasing Wage Inequality in Mexico?", World Development, 29 (11), 1905-22.

Cragg, M. and M. Epelbaum (1996); "Why has Wage Dispersion Grown in Mexico? Is it the Incidence of Reforms or the Growing Demand for Skills?", Journal of Development Economics, 51, 99-116.

Davis, D. (1996), “Trade Liberalization and Income Distribution”, NBER Working Paper 5693.

Easterly, W., N. Fiess and D. Lederman (2003) "NAFTA and Convergence in North America: High Expectations, Big Events, Little Time", mimeo, World Bank.

Epelbaum, M. and M. Cragg (1997). "La Creciente Desigualdad Salarial: ¿Elasticidades, Comercio Internacional o Tecnología?" In Gabriel Martínez (ed.): Pobreza y Política Social en México, Lecturas de El Trimestre Económico, 85, 297-322.

Feliciano, Z. (2001); "Workers and Trade Liberalization: The Impact of Trade Reforms in México on Wages and Employment", Industrial and Labor Relations Review, 55, 1, October, 95-115. 
Feenstra, R. and G. Hanson (1996). "Foreign Investment, Outsourcing and Relative Wages" in R. C. Feenstra, G. M. Grossman, and D. A. Irwin (eds.), Political Economy of Trade Policy: Essays in Honor of Jagdish Bhagwati, Cambridge: MIT Press, 89127.

Feenstra, R. and G. Hanson (1999). "The impact of outsourcing and high-technology capital on wages: estimates for the United States, 1979-1990," Quarterly Journal of Economics, 114(3), August, 907-940.

Galiani, S. and P. Sanguinetti (2003), "The Impact of Trade Liberalization on Wage Inequality: Evidence from Argentina", mimeo, NBER/Inter-American Seminar on Economics.

Gonzaga, G., N. Menezes-Filho and C. Terra (2002), "Trade liberalization and Evolution of Skill Earnings Differentials in Brazil", Working paper no. 463, Pontificia Universidade Católica do Rio de Janeiro, September.

Gottschalk, P. and T. Smeeding (1997), "Cross-national Comparisons of Earnings and Income Inequality, Journal of Economic Literature, 35, 633-687.

Haskel, J. and M. J. Slaughter (2001). "Trade, Technology and the UK Wage Inequality." The Economic Journal, 111 (January), 163-187.

Hanson, G. and A. Harrison (1999), "Trade Liberalization and Wage Inequality in Mexico", Industrial and Labor Relations Review, 52 (2), 271-288.

IADB (2002); "Regional Integration and Wage Inequality", chapter 12 in Economic and Social Progress Report.

Krueger, A. B. (1997). "Labor Market Shifts and the Price Puzzle Revisited." NBER Working Paper No. 5924.

Krugman, P. and R. Z. Lawrence (1993). “Trade, Jobs and Wages.” NBER Working Paper, 4478.

Krugman, P. (2000). "Technology, Trade and Factor Prices" Journal of International Economics, 50, 51-71.

Lawrence, R. Z. and M. J. Slaughter (1993). "International Trade and American Wages in the 1980s: Giant Sucking Sound or Small Hiccup?" Brooking Papers on Economic Activity, 2, 161-226.

Leamer, E. (1994); "Trade, Wages and Revolving Door Ideas", NBER Working Paper 4716, April. 
Leamer, E., (1996), "Wage Inequality from International Competition and Technological Change:Theory and Country Experience", American Economic Review, Papers and Proceedings, May 309-14.

Leamer, E. (1998). "In Search of Stolper-Samuelson Linkages between International Trade and Lower Wages." In Susan Collins (ed.): Imports, Exports and the American Worker, Brookings Institution, 141-202.

Meza, L (1999); "Cambios en la Estructura Salarial de México en el Periodo 1988-1993 y el Aumento en el Rendimiento en la Educación Superior", El Trimestre Económico, 66 (2), 189-226.

Meza, L. (2003); "Apertura Comercial y Cambio Tecnológico. Efectos en el Mercado Laboral Mexicano", El Trimestre Económico, forthcoming.

OECD (1997) 'Trade, Earnings and Employment: Assessing the Impact of Trade With Emerging Economies on OECD Labour Markets', Employment Outlook, Paris: OECD.

Robbins, D. (1996a), "Evidence on Trade and Wages in the Developing World", OECD Development Center, Technical Paper no. 119.

Robbins, D. (1996b); "HOS Hits Facts: Facts Win; Evidence on Trade and Wages in the Developing World", HIID Discussion Paper no. 557, October.

Robertson, R. (2001). "Relative Prices and Wage Inequality: Evidence from Mexico." Mimeo, Macalester College.

Sachs, J. D. and H. Shatz (1994); "Trade and Jobs in U.S. Manufacturing", Brookings Papers on Economic Activity, 1, pp. 1-84.

Slaughter, M. J. (2000); "What are the Results of Product-price Studies and What can we Learn from their Differences?", in R. Feenstra (ed.) The Impact of International Trade on Wages, Chicago University Press/NBER, 129-170.

Tornell, A. and G. Esquivel (1997); "The Political Economy of Mexico's entry to NAFTA" in T. Ito and A. O. Krueger (eds.), Regionalism Versus Multilateral Trade Arrangements, NBER-East Asia Seminar on Economics, Volume 6 (Chicago: University of Chicago Press), 1997, pp. 25-56.

Wood, A. (1995). "How Trade Hurt Unskilled Workers?" Journal of Economic Perspectives, Volume 9, No. 3, 57-80.

Wood, A. (1997), "Openness and Wage Inequality in Developing Countries: The Latin American Challenge to the East Asian Conventional Wisdom", World Bank Economic Review, 11, 1, 33-57. 